\title{
GLYCINE IN THE TREATMENT OF GOUT
}

BY

\section{FRED WRIGLEY}

The use of glycine and salicylate in the treatment of gout has now become fairly well established. This paper is to suggest a reconsideration of this form of therapy. Quick (1934), writing on " Uric Acid in Clinical Medicine ", says: " Of prime importance is the observation that under standardized and fixed conditions, the rate of uric acid excretion tends to be constant, is uninfluenced by the volume of urine, and is independent of the concentration of uric acid in the blood." The rate of uric acid excretion seems, therefore, dependent upon a metabolic process. Unlike creatinine, which is promptly excreted when fed, uric acid ingestion does not increase the hourly output. Quick then lists substances which increase and

TABLE I

EFFECT OF SALICYLIC ACID AND OF ACETYLSALICYLIC ACID ON URIC ACID EXCRETION. SYNERGISTIC ACTION OF GLYCINE

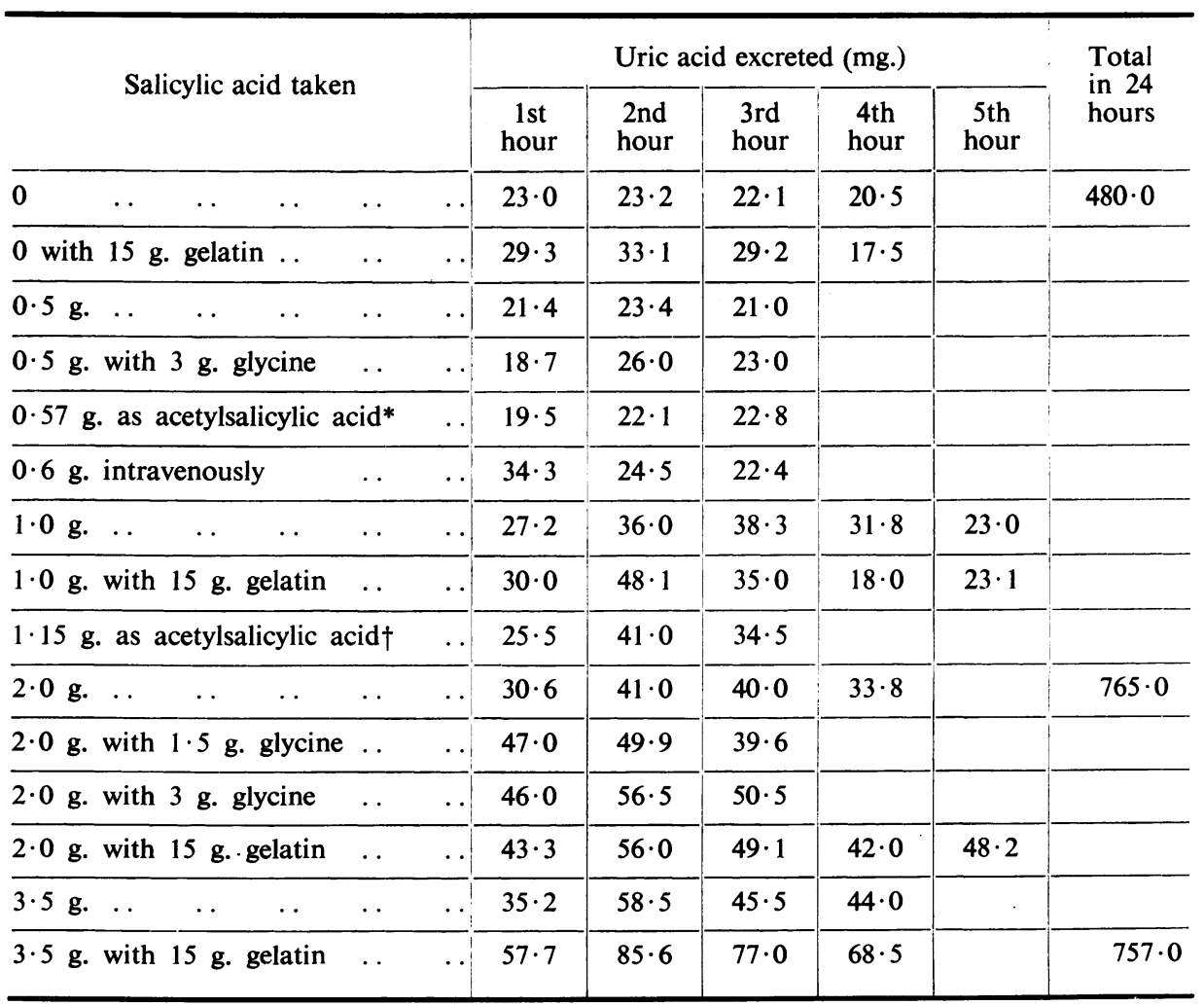

* $0.008 \mathrm{~g}$. of salicylic acid as acetylsalicylic acid excreted during the first hour.

$+0.014 \mathrm{~g}$. of salicylic acid as acetylsalicylic acid excreted during the first hour. 
decrease uric acid output. Amongst those said to increase uric acid output is glycine.

Quick (1933) reported the results of a very interesting and careful study and explained that there appeared to be a synergistic action between glycine and salicylic acid which should find therapeutic applications. His results are given in Table I. Unfortunately the parallel figures for the blood uric acid are not given.

The effect of glycine on the production and excretion of uric acid has been considered and discussed by Friedmann (1947). Although most people are agreed that ingestion of protein increases the output of uric acid in man, no one has yet made it clear why this takes place. Mares (1910) thinks that deterioration of the digestive cells concerned in the assimilation of ingested protein is responsible for increased urinary uric acid output following high protein feeding.

Taylor and Rose (1914) found that although uric acid excretion increased after protein intake, urinary creatinine did not change.

Dunn and others (1918) fed different amino acids to man and found that all those tested, except sarcosine, increased the output of uric acid and because this substance is not catabolized in the body, these workers suggest that the increased uric acid output after high protein diet was due to generalized cellular stimulation following the higher calorific intake.

Christman and Mosier (1929) administered glycine to several subjects and demonstrated that urinary uric acid was increased, but there was no change in the urinary excretion of creatinine. They agreed with Rose (1921) about the general stimulating effect of amino acids on metabolism, and the secondary increase of uric acid.

None of these investigators appears to have determined the concentration of blood uric acid after ingestion of amino acids, and it has merely been assumed that such a rise occurred because of the increased urinary output observed. Gibson and Doisy (1923), however, did not detect a rise in blood uric acid in man after the feeding of amino acids. Pitts (1943) showed that an excess of glycine might influence the renal excretion of a blood constituent by competing with it in the excretory system.

Friedman (1947) did both animal and human studies with glycine, but unfortunately he only treated two men. His results with the rat showed that increased uric acid output resulted in 17 of the 19 rats studied, the average uric acid output being $0 \cdot 136 \mathrm{mg}$. per hour before glycine was ingested, and $0 \cdot 170 \mathrm{mg}$. per hour afterwards. Thus there was an increase of 25 per cent. in uric acid output and the uric acid clearance also increased by about 35 per cent. The average volume decreased and the average creatinine clearance showed no significant change, and from these studies it was inferred that the increase in uric acid output after glycine ingestion is due neither to increased glomerular filtration, nor to increased renal blood flow. As far as the blood was concerned an increase of the blood uric acid took place in the control rats, and a similar increase was found in those rats given glycine (see Table II, overleaf). From this it is assumed that glycine per se does not increase the production of uric acid in the animal body. 
TABLE II THE EFFECT OF GLYCINE ON BLOOD URIC ACID IN THE RAT

\begin{tabular}{c|c|c|c|c|c|c}
\hline & \multicolumn{3}{|c|}{ Normal rat } & Normal & rats given glycine* \\
\hline Time & 10 a.m. & 12 noon & 3 p.m. & 10 a.m. & 12 noon & 3 p.m. \\
\hline $\begin{array}{c}\text { Average blood uric acid } \\
\text { in mg. per cent. } .\end{array}$ & 0.97 & 1.16 & 1.51 & 0.91 & 1.21 & 1.44 \\
\hline
\end{tabular}

* Each rat given $50 \mathrm{mg}$. of glycine per $100 \mathrm{~g}$. body-weight at start and then $5 \mathrm{mg}$. every hour of the 5-hour study period.

Experiments were also conducted on nephrectomized rats. The average blood uric acid level of 8 control rats before nephrectomy was $1.85 \mathrm{mg}$. per $100 \mathrm{cc}$. of blood; 24 hours after nephrectomy the blood concentration was $1 \cdot 88$, and it was 1.9648 hours after; this represents an increase of 6 per cent. in the blood uric acid 48 hours after nephrectomy. Nine rats were given glycine after nephrectomy, and the blood uric acid level, which was 1.71 before nephrectomy, was 1.80 after 24 hours and 1.84 after 48 hours, representing an increase of only 8 per cent. Thus it might be said that the feeding of glycine did not significantly raise the blood uric acid level of this group of rats; but since the rat converts uric acid into allantoin and any excess uric acid produced in these nephrectomized rats may have been so quickly converted to allantoin that no rise in blood uric acid occurred, the experimental data obtained from these nephrectomized rats cannot safely be applied to human subjects.

In the human experiments (see Table III) the ingestion of 25 grammes of glycine by two subjects was found to increase the uric acid output of both. The average uric acid output was $23.4 \mathrm{mg}$. per minute before the administration of glycine,

TABLE III

THE EFFECT OF GLYCINE ON BLOOD URIC ACID AND URIC ACID EXCRETION IN MAN

\begin{tabular}{|c|c|c|c|c|c|c|c|c|}
\hline \multirow{2}{*}{ Subject } & & \multicolumn{3}{|c|}{$\begin{array}{l}\text { Blood uric acid } \\
\text { in mg. per cent. }\end{array}$} & \multirow{2}{*}{ U.V. } & \multirow{2}{*}{ C.C. } & \multirow{2}{*}{ U.A.E. } & \multirow{2}{*}{ U.A.C } \\
\hline & & 10 a.m. & 12 noon & 3 p.m. & & & & \\
\hline $\begin{array}{cc}\text { Before } & \text { glycin } \\
\text { 1. } & . \\
2 . & \ldots\end{array}$ & $\begin{array}{l}. \\
\cdots\end{array}$ & $\begin{array}{l}3 \cdot 20 \\
3 \cdot 40\end{array}$ & $\begin{array}{l}3 \cdot 10 \\
3 \cdot 40\end{array}$ & $\begin{array}{l}3 \cdot 10 \\
3 \cdot 50\end{array}$ & $\begin{array}{l}3 \cdot 95 \\
2 \cdot 56\end{array}$ & $\begin{array}{l}115 \\
118\end{array}$ & $\begin{array}{l}19 \cdot 20 \\
27 \cdot 60\end{array}$ & $\begin{array}{l}10 \cdot 30 \\
13 \cdot 50\end{array}$ \\
\hline Average & .. & $3 \cdot 30$ & $3 \cdot 25$ & $3 \cdot 30$ & $3 \cdot 26$ & 116 & $23 \cdot 40$ & $11 \cdot 90$ \\
\hline $\begin{array}{cr}{ }^{*} \text { After } & \text { glycin } \\
1 . & . \\
2 . & . \\
\end{array}$ & $\begin{array}{l}5 g .): \\
\cdots \\
\cdots\end{array}$ & $\begin{array}{l}3 \cdot 60 \\
4 \cdot 00 \\
\end{array}$ & $\begin{array}{l}3 \cdot 60 \\
3 \cdot 90 \\
\end{array}$ & $\begin{array}{l}3.90 \\
3.90 \\
\end{array}$ & $\begin{array}{l}2 \cdot 50 \\
2 \cdot 48 \\
\end{array}$ & $\begin{array}{l}100 \\
101 \\
\end{array}$ & $\begin{array}{l}35 \cdot 60 \\
44 \cdot 30 \\
\end{array}$ & $\begin{array}{l}16 \cdot 10 \\
18 \cdot 90 \\
\end{array}$ \\
\hline Average & .. & $3 \cdot 80$ & $3 \cdot 75$ & $3 \cdot 90$ & $2 \cdot 49$ & 100 & $39 \cdot 95$ & $17 \cdot 50$ \\
\hline
\end{tabular}

U.V. = urine volume in $\mathrm{ml}$. per minute.

C.C. = creatinine clearance in $\mathrm{ml}$. per minute.

U.A.E. $=$ mg. of uric acid excreted in urine per minute.

U.A.C. $=$ uric acid clearance in $\mathrm{ml}$. per minute.

* Glycine given after the 10 a.m. blood sample had been obtained. 
and $39.95 \mathrm{mg}$. after, an increase of 71 per cent. Similarly, the average uric acid clearance increased from 11.9 to $17.5 \mathrm{ml}$. per minute, an increase of 47 per cent. As was observed in the rats, the average urinary volume also decreased from 3.26 ml. per minute before to $2.49 \mathrm{ml}$. after glycine, and the average creatinine clearance also decreased. Little or no change was observed in the blood uric acid level after glycine had been given.

These results lend colour to the suggestion that glycine does not increase the production of uric acid in the body of either rat or man; but it does not appear certain that glycine ingestion increases the renal excretion of uric acid, and it must be borne in mind that studies of creatinine and hippurate show clearly that there is no increase in the rate of glomerular filtration nor in the renal blood flow. Thus the author concludes that glycine probably impedes tubular re-absorption in some manner; in other words, that the uric acid output is increased, not because the kidney filters or secretes more of it, but because the tubules re-absorb less of it in the presence of excess glycine. Despite this explanation one can see throughout all these studies that the blood uric acid failed to decrease, but that in fact it actually increased a little, in spite of the increased renal output.

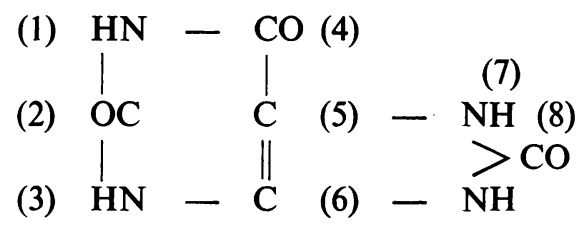

Fig. 1.-Uric Acid.

One might think there is not in these studies sufficient evidence to justify the administration of glycine to a case of gout. Later evidence points to the fact that the administration of glycine may actually promote the formation of uric acid.

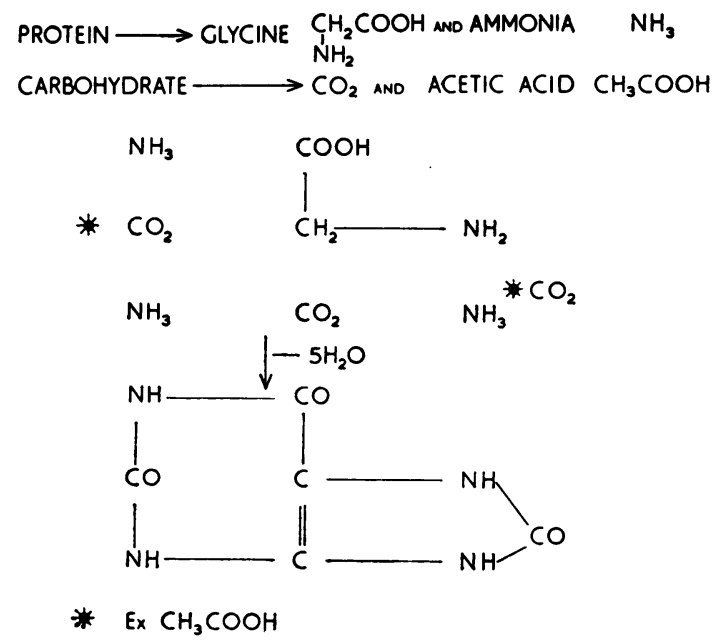

Fig. 2.-Possible biosynthesis of uric acid. 
Shemin and Rittenberg (1947) have shown in human subjects: (1) that glycine contributes nitrogen to position 7 in uric acid; and (2) that also in all probability carbon atom 5 is derived from the d-carbon atom of this amino acid.

Sonne and others (1946) worked on metabolism in the pigeon and pointed out that glycine, or a metabolic derivative of it, is probably the precursor of the $\mathrm{C}$ atoms 4 and $5 \mathrm{in}$ uric acid. The data obtained also leads them to think that $\mathrm{CO}_{2}$ is the precursor of $\mathrm{C}$ atom 6 and that the carboxyl carbon of acetate is the precursor of carbons 2 and 8 . A strictly diagrammatic representation of what may take place is shown in Fig. 2.

The ideas reviewed above are set out in the hope that further metabolic studies will be undertaken in normal and gouty patients, obtaining both blood and urinary uric acid figures. It may well be that if red cell and plasma uric acid is estimated we shall obtain useful information. In any case an attempt should be made to show what glycine really does and to determine its place in the treatment of gout.

\section{Summary}

The suggestion is advanced that the use of glycine in gout should be re-considered. The work leading up to its employment in this disease is discussed. It is pointed out that isotope studies have shown that glycine contributes some of the prosthetic groups for uric acid.

\section{REFERENCES}

Christman, A. A., and Mosier, E. C. (1929), J. biol. Chem., 83, 11.

Dunn, M. S., Lewis, H. B., and Doisy, E. A. (1918), Ibid., 36, 9.

Friedman, M. (1947), J. clin. Invest., 26, 815.

Gibson, H. V., and Doisy, E. A. (1923), J. biol. Chem., 55, 605.

Mares, F. (1910), Arch. ges. Physiol., 134, 59.

Pitts, R. F. (1943), Amer. J. Physiol., 140, 156.

Quick, A. J. (1933), J. biol. Chem., 101, 475.

- (1934). Med. Clin. N. Amer., 17, 1325.

Rose, W. C. (1921). J. biol. Chem., 48, 563.

Shemin, D., and Rittenberg, D. (1947). Ibid., 167, 875.

Sonne, J. C., Buchanan, J. M., and Delluva, A. M. (1946). Ibid., 166, 395.

Taylor, A. E., and Rose, W. C. (1914). Ibid., 18, 519.

\section{Glycine et Goutte}

RÉSUMÉ

On suggère que l'emploi de la glycine dans la goutte doit être reconsidérée. On discute les travaux qui ont mené a son application dans cette maladie et on indique que l'étude des isotopes a montré que la glycine contribue certains groupes prosthétiques à la formation de l'acide urique.

\section{La Glicina y la Gota \\ RESUMEN}

Se sugiere que la cuestión del empleo de la glicina en la gota merece una revisión. Se discute los trabajos que condujeron a su empleo en esta enfermedad y se señala que el estudio de los isotopes ha mostrado que la glicina contribuye ciertos grupos prostéticos a la formación del ácido úrico. 